\title{
Effects of Flourensia cernua ingestion on nitrogen balance of sheep consuming tobosa
}

\author{
D.W. KING, E.L. FREDRICKSON, R.E. ESTELL, K.M. HAVSTAD, J.D. WALLACE, AND \\ L.W. MURRAY
}

\begin{abstract}
Authors are beef nutritionist, 9101 63rd Ave., Dickinson, N.D. 58602; research animal scientist, USDA-ARS, Jornada Exp. Range, Las Cruces, N.M. 88003; research animal scientist, USDA-ARS, Jornada Exp. Range, Las Cruces, N.M.; research leader, USDA-ARS, Jomada Exp. Range; professor, Animal and Range Science Dept., New Mexico Stute Univ., Las Cruces, N.M.; and associate professor, Exp. Statistics Dept., New Mexico State Univ., Las Cruces, N.M., respectively. At the time of the research, the senior author was a graduate research assistant, Animal and Range Science Dept., New Mexico State Univ., Las Cruces, N.M.
\end{abstract}

\begin{abstract}
Flourensia cernua DC. (tarbush) is a deciduous shrub with potential as a high-protein forage source for livestock. Twentyfour Polypay $\times$ Rambouillet wethers housed in metaholism crates were used to evaluate tarbush as a $\mathbf{N}$ source for sheep fed a low quality grass diet. Treatments were $100 \%$ ground tobosa grass (Pleuraphis mutica Buckl.) or tobosa substituted with 10, 20, or $30 \%$ whole pre-bloom tarbush leaves $(n=5)$ or $26 \%$ ground alfalfa ( $n=4$, Medicago sativa $L_{\text {.) }}$ on a dry matter basis (dnb). Sheep were fed ad libitum for 11 days, after which feed was restricted to $1 \%$ (dmb) of body weight for 11 days to reduce sorting and maintain uniform intake. Apparent dry matter digestibility was not improved $(P=0.2646)$ with tarbush or alfalfa. Fecal $N$ was similar $(P=0.1626)$, but urinary $N$ varied $(P=$ $0.0008)$ among treatments. Apparent $\mathrm{N}$ digestibility differed $(P=$ $0.0042)$ among treatments $(43,46,50,56$, and $63 \%$ for sheep consuming $0,10,20$, or $30 \%$ tarbush or alfalfa, respectively). All treatments resulted in similar $(P=0.1569)$ but negative $\mathrm{N}$ retentions $\left(-2.4,-2.2,-2.8,-2.0\right.$, and $-1.5 \mathrm{~g}^{-1 a y^{-1}}$ for sheep consuming 0 , 10,20 , or $30 \%$ tarbush or alfalfa, respectively). Serum clinical profiles (day 22) confirmed all sheep were nutritionally stressed, but did not indicate toxicosis. Although neither tarbush nor alfalfa $\mathrm{N}$ compensated for the low quality basal diet, $\mathrm{N}$ from $30 \%$ tarbush was utilized with similar efficiency to alfalfa $\mathrm{N}$. The major impediment for using tarbush as a $\mathrm{N}$ source appeared to be low palatability.
\end{abstract}

Key Words: browse, digestibility, Flourensia cernua, Pleuraphis mutica, nitrogen balance, tarbush

Protein is a major limiting nutrient in New Mexico livestock diets (Wallace 1987) during periods of limited forage quality and/or quantity (Robertson 1987, Topps 1992). Shrubs tend to maintain higher levels of crude protein (CP) and phosphorus (P) than grasses or forbs during unfavorable growth conditions or dormancy (Holechek 1984, Holechek et al. 1989). Browse may provide a vital source of crude protein for livestock at these times

\footnotetext{
The authors gratefully acknowledge the assistance of Brian Oetting, Dan Dhuyvetter, and Carol Slator.

Manuscript accepted 8 Sept. 95.
}

(Kumar and Singh 1984, Nunez-Hernandez et al. 1989, Ho Ahn et al. 1989).

Tarbush (Flourensia cermua DC.) is increasing in dominance in the Chihuahuan Desert (Buffington and Herbel 1965) and is high in crude protein (Nelson et al. 1970). However, tarbush contains several secondary compounds with potential to reduce palatability and/or impede $\mathrm{N}$ digestion and utilization. Tarbush phytochemicals include flavonoids (Rao et al. 1970, Dillon et al. 1976), terpendoids (Kingston et al. 1975, Estell et al. 1994), and phenolics (Unpublished data, Estell et al.).

Plant secondary metabolites exert detrimental effects on herbivores when doses exceed threshold levels (Harborne 1991) which are undefined for most plant chemicals (Butler 1989): It is not known if tarbush secondary metabolites are present in forms and/or quantities necessary to hinder use of the relatively high protein concentrations in this shrub. The objective of this study was to evaluate the digestibility and retention of tarbush $\mathrm{N}$ in sheep consuming a poor quality tobosa grass diet.

\section{Materials and Methods}

\section{Plant Collection}

Tarbush and tobosa grass (Pleuraphis mutica Buckl.) were collected at the USDA-ARS Jornada Experimental Range, $35 \mathrm{~km}$ north of Las Cruces, N.M., during August 1991. Tarbush was harvested in the pre-bloom stage, whereas tobosa was mature and contained considerable proportions of dead material. Collection of both shrubs and grass is described in detail in the companion paper (King et al. 1996). Third-cutting alfalfa (Medicago sativa L.) was purchased locally.

\section{Experimental Protocol}

Twenty-four yearling Polypay $\times$ Rambouillet wethers $(46.9 \mathrm{~kg}$, $S E=2.9$ ) were housed in individual metabolism crates in a climate-controlled facility at New Mexico State University, Las Cruces. Care and handling of animals was in accordance with guidelines established by the New Mexico State University Institutional Animal Care and Use Committee. Twelve hours of light and free access to water and trace mineral salt blocks $(\mathrm{NaCl}$ $96-99 \%, \mathrm{Mn}>0.2 \%, \mathrm{Fe}>0.1 \%, \mathrm{Mg}>0.1 \%, \mathrm{~S}>0.05 \%, \mathrm{Cu}>$ 
$0.025 \%, \mathrm{Co}>0.01 \%, \mathrm{Zn}>0.008 \%$, and $\mathrm{I}>0.007 \%$; United Salt Corp., Houston, Tex.) were provided daily. Wethers were allotted to 1 of 5 treatments $(\mathrm{n}=5$ for $0,10,20$, and $30 \%$ tarbush treatments, $\mathrm{n}=4$ for the alfalfa treatment) in a completely random design. Treatments were $100 \%$ ground $(2.54-\mathrm{cm}$ screen) tobosa or tobosa substituted with 10,20 , or $30 \%$ pre-bloom whole tarbush leaves or $26 \%$ ground $(2.54-\mathrm{cm}$ screen) alfalfa. The $30 \%$ tarbush and alfalfa treatments were formulated to be isonitrogenous. One sheep each from the 0,20 , and $30 \%$ tarbush treatments contracted pneumonia during the adaptation period and was removed from the study. Consequently, all treatments contained 4 sheep except $10 \%$ tarbush.

Experimental diets were hand-mixed and fed twice daily at 0700 and 1700 hours. Animals were allowed ad libitum access to diets for 11 days. However, substantial refusals and sorting were encountered on all but the alfalfa treatment. Hence, on day 12, feed was restricted to $1 \%$ of body weight (BW) to reduce sorting and maintain all treatments at similar dry matter intake (DMI) levels. Following feed restrictions, sheep were permitted another 5 days of adaption which was followed by 5 days of total fecal and urine collections.

\section{Sample Collection}

Feed refusals were measured daily. Samples of feed and orts were composited by sheep, and subsamples of each were ground to pass a 2-mm screen. From day, 17 through 21, total fecal output and urine volume were monitored and $10 \%$ aliquots were retained daily for each sheep. Volatilization of ammonia from urine was prevented by adding $10 \mathrm{ml}$ of $50 \% \mathrm{HCl}$ to collection vessels. Urine collections were stored at $4^{\circ} \mathrm{C}$ until day 21 . Individual feces and urine subsamples were then composited by sheep across days, and urine composites were frozen. Fecal subsamples were partially dried at $50^{\circ} \mathrm{C}$ for 72 hours, and then ground (2-mm screen) and analyzed for dry matter (DM) and ash (AOAC 1984). Sheep were weighed following a 12 hour fast before and after the trial. Blood $(10 \mathrm{ml})$ was collected on day 22 via jugular venipuncture before the 0700 hour feeding. Blood samples were allowed to clot at room temperature for $30 \mathrm{~min}$, centrifuged at $2,300 \times \mathrm{g}$ for $15 \mathrm{~min}$ at $4^{\circ} \mathrm{C}$, and serum was decanted and frozen $\left(-10^{\circ} \mathrm{C}\right)$.

\section{Chemical Analyses}

Chemical analyses were conducted on feed, orts, and feces. All $\mathrm{N}$ fractions were analyzed by macro Kjeldahl methods (AOAC 1984). Neutral detergent fiber (NDF), acid detergent fiber (ADF), acid detergent lignin (ADL), and acid detergent insoluble $\mathrm{N}$ (ADIN) of diet ingredients and orts were evaluated by nonsequential procedures of Goering and Van Soest (1970). Total phe- nolic content of feeds was measured according to the Folin-Denis method (AOAC 1984). Condensed tannin concentration of feeds was determined by the vanillin/ $\mathrm{HCl}$ procedure of Burns (1971) as modified by Price et al. (1978). Serum constituents were measured using an automated multichannel serum analyzer (Chem30, Southwest Laboratories, Las Cruces, N.M.).

\section{Statistical Analyses}

Data was analyzed as a completely random design. Analysis of variance was conducted with GLM procedures of SAS Institute (1989). Treatment means were separated by predicted difference when a significant $F$-test $(P<0.05)$ for the overall model was detected.

\section{Results}

\section{Chemical Composition of Diet Ingredients}

Chemical analysis of dietary ingredients is shown in Table 1. Tobosa contained low levels of crude protein (CP) $(5.9 \%)$ and a high fiber content $(80.7 \% \mathrm{NDF})$. Tarbush and alfalfa were similar in CP at 18.9 and $20.1 \%$, respectively. Tobosa and tarbush both contained higher percentages of acid detergent insoluble $\mathrm{N}$ (ADIN) than alfalfa. About 28,12 , and $7 \%$ of the total $\mathrm{N}$ of tobosa, tarbush, and alfalfa, respectively, were comprised of ADIN. Condensed tannins and phenolics were greater in tarbush than in tobosa or alfalfa.

\section{Dry Matter Intake}

Feed restrictions imposed on day 12 eliminated differences $(P=$ 0.7964) in dry matter intake (DMI) (Table 2) and limited all sheep to intakes of approximately $1 \%$ of BW. Even at this level of DMI, a few individuals on all but the alfalfa treatment still exhibited minor feed refusals. Intakes were $8.4,8.3,9.1,9.8$, and $10.0 \mathrm{~g} \mathrm{DM} \mathrm{kg}^{-1} \mathrm{BW}$ for tobosa, 10,20 , and $30 \%$ tarbush and alfalfa treatments, respectively.

\section{Daily Fecal and Urine Output}

Total fecal output did not differ $(P=0.8822)$ among treatments, ranging from 245 to $295 \mathrm{~g} \mathrm{DM}^{\text {day }}{ }^{-1}$ (Table 2). Because feed intake was similar, this result was not surprising.

Daily urine volume was similar $(P=0.2330)$ among treatments. Although means ranged from 647 to $2,131 \mathrm{ml}^{\text {day }}{ }^{-1}$ (Table 2), a high $S E$ (469) precluded detection of differences. Urine volumes were monitored the entire trial for a companion study examining excretory metabolites of tarbush. One wether consuming $30 \%$ tarbush excreted as much as twice the volume of urine day ${ }^{-1}(4,500$ $\mathrm{ml}^{\left.-\mathrm{day}^{-1}\right)}$ as any other wether, but this individual exhibited polyuria from the trial onset. Consequently, this individual inflat-

Table 1. Chemical analysis of ingredients used in diets of sheep fed a low quality diet with $0,10,20$, or $30 \%$ of the dietary dry matter (DM) as tarbush, or $26 \%$ of the dietary dry matter as alfalfa'.

\begin{tabular}{|c|c|c|c|c|c|c|c|}
\hline Item & $\mathrm{CP}$ & ADIN & NDF & $\mathrm{ADF}$ & $\mathrm{ADL}$ & $\begin{array}{c}\text { Condensed } \\
\text { tannins }\end{array}$ & $\begin{array}{c}\text { Total } \\
\text { phenolics }\end{array}$ \\
\hline & --- & --- & $\%$ of $\mathrm{DI}$ & --- & ---- & $C \mathrm{E}^{2}$ & $\mathrm{mg} \mathrm{g}^{-1} \mathrm{DM}$ \\
\hline Tobosa & 5.9 & 0.26 & 80.7 & 55.3 & 12.2 & 0.04 & 11.9 \\
\hline Alfalfa & 20.1 & 0.22 & 35.8 & 26.3 & 7.7 & 0.09 & 14.6 \\
\hline
\end{tabular}

${ }_{2} \mathrm{CP}=$ crude protein, $\mathrm{ADN}=$ acid detergent insoluble $\mathrm{N}, \mathrm{NDF}=$ neutral detergent fiber, $\mathrm{ADF}=$ acid detergent fiber, and $\mathrm{ADL}=\mathrm{acid}$ detergent lignin .

${ }^{2} \mathrm{CE}=$ catechin equivalents ( $\mathrm{mg} 100 \mathrm{mg}^{-1} \mathrm{DN}$ ). 
Table 2. Dry matter intake (DMI), fecal and urine output, dry matter digestibility (DMD), $\mathbf{N}$ balance, and body weight (BW) changes of sheep fed a low quality tobosa diet $(5.9 \% \mathrm{CP})$ with $0,10,20$, or $30 \%$ of the dietary dry matter (DM) as tarbush (18.9\% CP), or $26 \%$ of the DM as alfalfa (20.1\% CP).

\begin{tabular}{|c|c|c|c|c|c|c|c|}
\hline \multirow[b]{2}{*}{ Item } & \multicolumn{5}{|c|}{ Treatments } & \multirow[b]{2}{*}{$S E^{I}$} & \multirow[b]{2}{*}{$O S L^{2}$} \\
\hline & $\begin{array}{c}\text { 100\% } \\
\text { Tobosa }\end{array}$ & $\begin{array}{c}10 \% \\
\text { Tarbush }\end{array}$ & $\begin{array}{c}20 \% \\
\text { Tarbush }\end{array}$ & $\begin{array}{c}30 \% \\
\text { Tarbush }\end{array}$ & $\begin{array}{c}26 \% \\
\text { Alfalfa }\end{array}$ & & \\
\hline DMI, g day ${ }^{-1}$ & 399.4 & 387.0 & 441.0 & 438.0 & 471.8 & 55.4 & 0.7964 \\
\hline $\begin{array}{l}\text { Fecal output, g DM } \\
\text { day }^{-1}\end{array}$ & 253.0 & 244.9 & 295.3 & 282.6 & 259.3 & 37.2 & 0.8822 \\
\hline $\mathrm{N}$ intake, g day ${ }^{-1}$ & $3.8^{\mathrm{a}}$ & $4.4^{a b}$ & $5.9^{\mathrm{bc}}$ & $6.8^{\mathrm{c}}$ & $7.2^{\mathrm{c}}$ & 0.63 & 0.0043 \\
\hline Fecal N, g day ${ }^{-1}$ & 2.1 & 2.3 & 2.9 & 3.0 & 2.7 & 0.28 & 0.1626 \\
\hline Urinary $\mathrm{N}, \mathrm{g}$ day ${ }^{-1}$ & $4.0^{\mathrm{a}}$ & $4.3^{\mathrm{a}}$ & $5.9^{\mathrm{b}}$ & $5.7^{\mathrm{b}}$ & $6.0^{b}$ & 0.34 & 0.0008 \\
\hline $\mathrm{N}$ balance, $\mathrm{g}$ day ${ }^{-1}$ & -2.4 & -2.2 & -2.8 & -2.0 & -1.5 & 0.36 & 0.1569 \\
\hline $\mathrm{N}$ digestibility, $\%$ & $43.0^{\mathrm{a}}$ & $45.5^{\mathrm{a}}$ & $49.7^{\mathrm{ab}}$ & $55.6^{\mathrm{bc}}$ & $63.1^{\mathrm{c}}$ & 3.39 & 0.0042 \\
\hline BW change, $\mathrm{kg}$ & -6.6 & -6.2 & -6.5 & -5.9 & -4.2 & 0.6 & 0.0657 \\
\hline
\end{tabular}

a,b.c Least Square Means within row without a common superscript differ $(P<0.05)$.

Standard error of treatment Least Square Means, $n=21$.

2 Observed significance level of $F$-statistic for treatment.

ed mean urine output for the $30 \%$ tarbush treatment and was responsible for much of the increased variability. Mean urine volume for both the 20 and $30 \%$ tarbush treatments was above that of the other treatments from the onset of the trial; hence, urine volumes had limited interpretive value.

\section{Dry Matter Digestibility}

No treatment effect $(P=0.2646)$ was observed for dry matter digestibility (DMD, Table 2). Mean DMD was 37, 37, 32, 36, and $45 \%$ for tobosa, 10, 20, and $30 \%$ tarbush, and alfalfa diets, respectively. Additional dietary crude protein (CP), especially from tarbush, did not appear to stimulate forage digestion. Possibly, the low dry matter intake (DMI) negated any advantage of increasing dietary $\mathrm{CP}$.

\section{Nitrogen Intake}

Nitrogen intake varied $(P=0.0043)$ among treatments (Table 2). Differences were expected because only $30 \%$ tarbush and $26 \%$ alfalfa treatments were isonitrogenous. The treatments spanned a crude protein (CP) concentration range typical of that consumed by livestock under free ranging conditions when differing amounts of browse or commercial protein supplements are consumed along with low quality grass diets. Nitrogen intake of sheep fed alfalfa $\left(7.2 \mathrm{~g}\right.$ day $\left.^{-1}\right), 30 \%$ tarbush $\left(6.8 \mathrm{~g}\right.$ day $\left.^{-1}\right)$, and $20 \%$ tarbush $\left(5.9 \mathrm{~g} \mathrm{day}^{-1}\right)$ did not differ $(P>0.05)$. Nitrogen intake of sheep fed $10 \%$ tarbush $\left(4.4 \mathrm{~g} \mathrm{day}^{-1}\right)$ did not differ from sheep fed the 0 or 20\% tarbush treatments, and $\mathrm{N}$ intake of sheep fed $0 \%$ tarbush (3.8 $\left.\mathrm{g} \mathrm{day}^{-1}\right)$ did not differ from sheep fed the $10 \%$ treatment $(P>0.05)$.

\section{Nitrogen Excretion}

Fecal $\mathrm{N}$ output did not differ $(P=0.1626)$ among treatments (Table 2). However, when fecal $\mathrm{N}$ excretion was expressed as a percentage of $N$ intake to account for the influence of $N$ intake on N loss (Nunez-Hernandez et al. 1991), treatment differences $(P=$ 0.0042 ) were evident. As a percentage of $\mathrm{N}$ intake, fecal $\mathrm{N}$ was $57,55,50,44$, and $37 \%$ for $0,10,20$, and $30 \%$ tarbush and alfalfa treatments, respectively. The percentage of $\mathrm{N}$ excreted in the feces declined as protein increased, regardless of whether protein was from tarbush or alfalfa.

Urinary $\mathrm{N}$ differed $(P=0.0008)$ among treatments. Urinary $\mathrm{N}$ losses were $4.0,4.3,5.9,5.7$, and $6.0 \mathrm{~g} \mathrm{day}^{-1}$ for $0,10,20$, and $30 \%$ tarbush and alfalfa, respectively. Urinary $\mathrm{N}$ losses were lower $(P<$ 0.05 ) for the 0 and $10 \%$ tarbush treatments than for the other 3 treatments. Expressed as a percentage of $\mathrm{N}$ intake, urinary $\mathrm{N}$ losses were similar $(P=0.4952)$ among treatments. Sheep on 0,10 , and $20 \%$ tarbush treatments excreted more $\mathrm{N}$ in the urine than was consumed $(128,107$, and $108 \%$, respectively). Those fed $30 \%$ tarbush or alfalfa excreted only 85 or $83 \%$ of their $\mathrm{N}$ intake in the urine.

\section{Apparent Nitrogen Digestibility}

Apparent $\mathrm{N}$ digestibility was affected $(P=0.0042)$ by level of dietary tarbush or alfalfa (Table 2). Treatment means were 43.0, $45.5,49.7,55.6$, and $63.1 \%$ for tobosa, 10,20 , and $30 \%$ tarbush and alfalfa, respectively. Apparent $\mathrm{N}$ digestibility of the $30 \%$ tarbush and alfalfa treatments was not different, and $\mathrm{N}$ digestibility of the $30 \%$ tarbush treatment did not differ from the $20 \%$ treatment $(P>0.05)$. Apparent $\mathrm{N}$ digestibility of sheep fed 0,10 , and $20 \%$ tarbush was not different $(P>0.05)$. Increased dietary tobosa was associated with an increased acid detergent insoluble $\mathrm{N}$ (ADIN) proportion. As a percentage of total N, ADIN composed $28 \%$ of the tobosa $\mathrm{N}, 12 \%$ of the tarbush $\mathrm{N}$, and only $7 \%$ of the alfalfa $\mathrm{N}$.

\section{Nitrogen Retention}

Tarbush and alfalfa both contained high levels of crude protein (CP) compared to the tobosa which contained only $5.9 \% \mathrm{CP}$ (Table 1). However, neither dietary tarbush nor alfalfa (at the levels fed) was able to overcome the CP deficit for the basal diet. Sheep on all treatments experienced negative but similar $(P=$ 0.1569 ) $\mathrm{N}$ balances (Table 2). Nitrogen losses were $-2.4,-2.2$, $-2.8,-2.0$, and $-1.5 \mathrm{~g} \mathrm{day}^{-1}$ for the $0,10,20$, and $30 \%$ tarbush and alfalfa treatments, respectively. 


\section{Body Weight Changes}

Initial mean body weight (BW) $(P=0.9035)$ and final BW $(P=$ $0.8158)$ were similar across treatment. Although a trend $(P=$ 0.0657 ) was evident for sheep consuming alfalfa to maintain more of their BW (Table 2), this was not considered important as dry matter intake differences during the first 11 days confounded analysis of BW changes.

\section{Blood Clinical Profiles}

No treatment effects were detected $(P>0.05)$ for serum metabolites, enzymes, or most electrolytes (data not shown). Hence, the serum constituents monitored did not indicate any present or impending toxicosis. Serum variables did confirm sheep on all treatments were nutritionally stressed.

Cholesterol levels $\left(78.5-88.8 \mathrm{mg} \mathrm{dl}^{-1}\right)$ were several times greater than triglycerides $\left(7.0-10.0 \mathrm{mg} \mathrm{dl}^{-1}\right)$, which is indicative of animals mobilizing body reserves. This ratio in conjunction with body weight (BW) losses suggested animals were utilizing dietary protein for gluconeogenesis and energy rather than body protein accretion.

Blood urea N (BUN) concentrations were 9.8, 10.8, 10.0, 11.0, and $14.8 \mathrm{mg} \mathrm{dl}^{-1}(S E=1.4)$ for tobosa, 10, 20, and 30\% tarbush and alfalfa, respectively. Although BUN values were normal (Kaneko 1989), they were below those indicative of well nourished sheep (16-20 $\left.\mathrm{mg} \mathrm{dl}^{-1}\right)$.

\section{Discussion}

Several variables monitored were adversely affected by the low palatability of both tobosa and tarbush leaves. Poor animal acceptance of experimental diets led to dry matter (DM) and $\mathrm{N}$ intakes below maintenance levels, which confounded digestibility and $N$ retention results.

It is difficult to maintain intake of low or marginally palatable diets when animals are confined to metabolism crates. Intake levels in the current trial were approximately half of those obtained by Nunez-Hernandez (1989) for sheep and goats in metabolism crates fed prairie grass hay and 25 or $50 \%$ of the more palatable mountain mahogany (Cercocarpus montanus Raf.). However, our intakes were comparable to those reported by Nunez-Hernandez et al. (1989) for goats fed the less palatable big sagebrush (Artemisia tridentata Nutt. ssp. tridentata). Holechek et al. (1990) reported intakes ranging from 0.4 to $1.3 \%$ of body weight (BW) (omb) for goats fed straw-shrub diets containing either 18\% honey mesquite (Prosopis glandulosa Torr.), 25\% common winterfat (Eurotia lanata [Pursh] Moq.), 23\% fourwing saltbrush (Atriplex canescens [Pursh] Nutt.), 10\% creosotebush (Larrea tridentata [DC.] Cov.), 50\% gray oak (Quercus grisea Liebm.), or 17\% 1-seed juniper (Juniperus monosperma [Engelm.] Sarg.).

Concerns that tarbush secondary metabolites might influence $\mathbf{N}$ retention were not supported by the data. Significant or numerical differences in $\mathrm{N}$ retention or $\mathrm{N}$ digestibility appeared related to $\mathrm{N}$ intake, energy balance, or physical plant factors such as acid detergent insoluble $N$ (ADIN). The fact that $N$ from the $30 \%$ tarbush diet and the isonitrogenous alfalfa treatment were used with similar efficiency supports this view. The higher proportion of tarbush $\mathrm{N}$ from ADIN compared to alfalfa may account for small numerical differences in $\mathrm{N}$ balance between the $30 \%$ tarbush and alfalfa treatments (Table 2).

Especially of concern for $\mathrm{N}$ utilization was the condensed tan- nin content of tarbush. However, $\mathrm{N}$ degradation or $\mathrm{N}$ assimilation did not appear related to condensed tannin concentration. Nastis and Malechek (1981) and Barry et al. (1986) found increasing levels of dietary condensed tannins resulted in elevated fecal $\mathbf{N}$. While increased fecal $\mathrm{N}$ was confirmed by Nunez-Hernandez et al. (1989, 1991), they found concurrent $\mathrm{N}$ sparing in the urine. During the current trial, $\mathrm{N}$ excretion appeared related to dietary $\mathrm{N}$ content.

Serum metabolite profiles in conjunction with body weight (BW) loss indicated sheep on all treatments were nutritionally stressed and likely mobilizing body reserves. In addition to low dry matter intake (DMI), diets were composed primarily of poor quality tobosa ( $81 \% \mathrm{NDF})$. Thus, animals were probably energy deficient and using some dietary protein for gluconeogenesis and other energetic processes, which could explain at least partially why responses to increased protein consumption were lower than anticipated.

In conclusion, tarbush leaves fed at up to $30 \%$ of the diet and $1 \%$ of $B W$ for 22 days did not improve $N$ retention in sheep consuming poor quality tobosa grass. However, $\mathrm{N}$ in the $30 \%$ tarbush and isonitrogenous alfalfa treatments was utilized with simialr efficiency, indicating that tarbush could supply $\mathrm{CP}$ to grazing animals and improve their nutritional welfare, assuming sufficient DMI could be achieved. Secondary chemistry, while not influencing $N$ balance directly, probably limited acceptance of tarbush leaves by sheep. More work is required to ascertain whether free ranging livestock can be manipulated to consume enough tarbush to elicit a nutritional benefit.

\section{Literature Cited}

AOAC. 1984. Official Methods of Analysis (14th ed.) Assoc. Official Analytical Chemists. Washington, D.C.

Barry, T.N., T.F. Allsop, and C. Redekopp. 1986. The role of condensed tannins in the nutritional value of Lotus pedunculatus for sheep. 5. Effects on the endocrine system and on adipose tissue metabolism. Brit. J. Nutr. 56:607-614.

Buffington, L.C. and C.H. Herbel. 1965. Vegetational changes on a semidesert range. Ecol. Monogr. 35:139-149.

Burns, R.E. 1971. Method for estimation of tannin in grain sorghum. Agron. J. 63:511-519.

Butler, L.G. 1989. Effects of condensed tannin on animal nutrition. In: R.W. Hemingway and J.J. Karchesy (ed.), Chemistry and significance of condensed tannins. Plenum Press, New York, N.Y.

Dillon, M.O., T.J. Mabry, E. Besson, M.L. Bouillant, and J. Chopin. 1976. New flavonoids from Flourensia cernua. Phytochem. 15:1085-1088.

Estell, R.E., K.M. Havstad, E.L. Fredrickson, and J.L. GardeaTorresday. 1994. Secondary chemistry of the leaf surface of Flourensia cernua. Biochem. Syst. Ecol. 22:73-77.

Goering, H.K. and P.J. Van Soest. 1970. Forage fiber analyses (apparatus, reagents, procedures and some applications). USDA-ARS Handbook No. 379, Washington, D.C.

Harborne, J.B. 1991. Flavonoid pigments. In: G.A. Rosenthal and M.R. Berenbaum (ed.), Herbivores, their interaction with secondary metabolites. Academic Press, Inc., New York, N.Y. pp. 389-430.

Ho Ahn, J., B.M. Robertson, R. Elliot, R.C. Gutteridge, and C.W. Ford. 1989. Quality assessment of tropical browse legumes: tannin content and protein degradation. Anim. Feed Sci. Tech. 27:147-156.

Holechek, J.L. 1984. Comparative contribution of grasses, forbs, and shrubs to the nutrition of range ungulates. Rangelands 6:261-263.

Holechek, J.L., R.D. Pieper, and C.H. Herbel. 1989. Range management principles and practices. Prentice Hall Publ. Co., Englewood Cliffs, N.J. 
Holechek, J.L., A.V. Munshikpu, L. Saiwana, G. Nunez-Hernandez, R. Valdez, J.D. Wallace, and M. Cardenas. 1990. Influences of six shrub diets varying in phenol content on intake and nitrogen retention by goats. Trop. Grassl. 24:93-98.

Kaneko, J.J. 1989. Clinical biochemistry of domestic animals, fourth edition. Academic Press Inc., New York, N.Y.

King, D.W., R.E. Estell, E.L. Fredrickson, K.M. Havstad, J.D. Wallace, and L.W. Murray. 1996. Effects of Flourensia cernua ingestion on intake, digesta kinetics, and ruminal fermentation of sheep consuming tobosa. J. Range Manage. 49:325-330..

Kingston, D.G.I., M.M. Rao, T.D. Spittler, R.C. Petterson, and D.L. Cullen. 1975. Sesquiterpenes from Flourensia cernua. Phytochem. 14:2033-2037.

Kumar, R. and M. Singh. 1984. Tannins: their adverse role in ruminant nutrition. J. Agr. Food Chem. 32:447-453.

Nastis, A.S. and J.C. Malechek. 1981. Digestion and utilization of nutrients in oak browse by goats. J. Anim. Sci. 53:283-289.

Nelson, A.B., C.H. Herbel, and H.M. Jackson. 1970. Chemical composition of forage species grazed by cattle on arid New Mexico range. N.M. Agr. Exp. Sta. Bull. No. 561 .

Nunez-Hernandez, G. 1989. Influence of condensed tannins on nitrogen digestibility and balance, serum urea-N, growth hormone and insulin, forage digestion and ruminal fermentation in angora goats and sheep fed low-quality diets containing Mountain Mahogany (Cercocarpus montanus). Ph.D. Diss., New Mexico State Univ., Las Cruces, N.M.
Nunez-Hernandez, G., J.L. Holechek, J.D. Wallace, M.L. Galyean, A. Tempo, R. Valdez, and M. Cardenas. 1989. Influence of native shrubs on nutritional status of goats: nitrogen retention. J. Range Manage. 42:228-232.

Nunez-Hernandez, G., J.D. Wallace, J.L. Holechek, M.L. Galyean, and M. Cardenas. 1991. Condensed tannins and nutrient utilization by lambs and goats fed low-quality diets. J. Anim. Sci. 69:1167-1177.

Price, M.L., S. Van Scoyoc, and L.G. Butler. 1978. A critical evaluation of the vanillin reaction as an assay for tannin in sorghum grain. J. Agr. Food Chem. 26:1214-1219.

Rao, M.M., D.G.I. Kingston, and T.D. Spittler. 1970. Flavonoids from Flourensia cermua. Phytochem. 9:227-232.

Robertson, G. 1987. Effect of drought and high summer rainfall on biomass and composition of grazed pastures in western New South Wales. Australian Rangel. J. 9:79-85.

SAS Institute. 1989. SAS User's Guide: Statistics, Version 6.07. SAS Institute, Inc. Cary, N.C.

Topps, J.H. 1992. Potential, composition and use of legume shrubs and trees as fodders for livestock in the tropics. J. Agr. Sci. (Camb.) 118:1-8.

Wallace, J.D. 1987. Supplemental feeding options to improve livestock efficiency on rangelands. In: R.S. White and R.E. Short (ed.), Achieving efficient use of rangeland resources. Fort Keogh Res. Symp., USDA-ARS, Miles City, Mont., pp. 92-100.

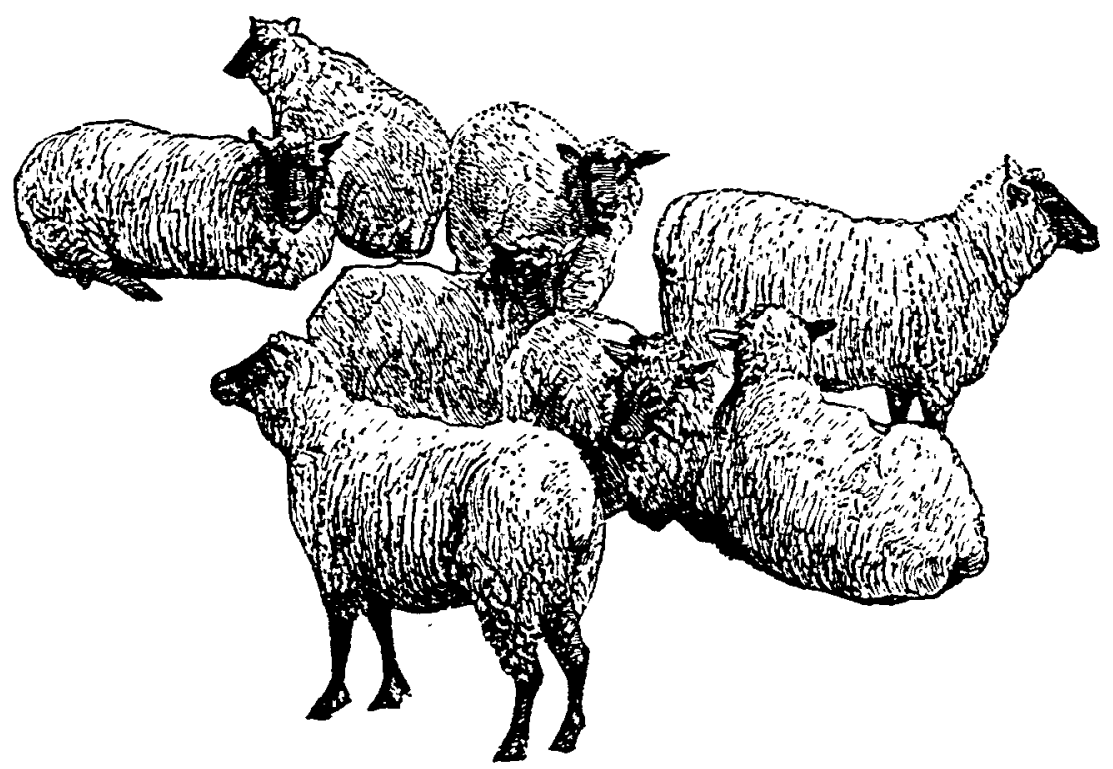

